\title{
PENGARUH PERKEMBANGAN PARIWISATA TERHADAP PERUBAHAN ALIH FUNGSI LAHAN DI DESA CANGGU KECAMATAN KUTA UTARA KABUPATEN BADUNG
}

\author{
I Made Kartika \\ Program Studi Pendidikan Pancasila dan Kewarganegaraan, Fakultas Keguruan Dan Ilmu Pendidikan \\ Universitas Dwijendra Denpasar \\ email : kartika@undwi.ac.id
}

\section{Gede Sujana}

Program Studi Pendidikan Pancasila dan Kewarganegaraan, Fakultas Keguruan Dan Ilmu Pendidikan Universitas Dwijendra Denpasar email : gedesujana@undwi.ac.id

\author{
Alquinus Jehapu \\ Program Studi Pendidikan Pancasila dan Kewarganegaraan, Fakultas Keguruan Dan Ilmu Pendidikan \\ Universitas Dwijendra Denpasar \\ email : alquinusjehapu80835@gmail.com
}

\begin{abstract}
Abstrak
Canggu adalah sebuah desa yang terletak di kabupaten Kuta Utara, Kabupaten Badung sebagai Daerah Pengembangan Badung Tengah yang memiliki kebijakan mempertahankan Badung Tengah sebagai daerah pertanian dalam arti luas dan mencegah konversi sawah. Pertanyaan penelitian dari penelitian ini adalah tentang dampak pariwisata terhadap konversi lahan. Pemilihan desa Canggu sebagai lokasi penelitian karena desa Canggu berada di tengah-tengah wilayah Badung sebagai daerah pertanian, alam dan budaya sebagai semangat pariwisata desa Canggu, desa Canggu dipengaruhi oleh pembangunan fasilitas akomodasi. Jenis data dalam penelitian ini adalah sumber data kualitatif dan kuantitatif dari data primer dan sekunder. Data penelitian ini dikumpulkan melalui wawancara dan studi kepustakaan. Penentuan informan penelitian ini dimulai dengan menentukan informan pertama dan informan kunci. Teknik analisis data penelitian ini adalah analisis deskriptif kualitatif. Menurut hasil penelitian di desa Canggu didapat hasil sebagai berikut pengembangan pariwisata berdampak pada peningkatan konversi lahan pertanian, perubahan penggunaan lahan juga berdampak pada perubahan sosiokultural. Adapun lokasi penelitian ditentukan berdasarkan perkembangan pariwisata terhadap alih fungui lahan, hasil dari penelitian ini perkembangan pariwisata terhadap alih fungsi lahan berdampak pada kesejahtraan masyarakat Desa Canggu. Lahan yang dialih fungsikan dibangun Hotel, Homestay, Villa, Restoran, Laundry dan lain sebagainya yang menunjang ketertarikan wistawan, untuk berwisata ke Desa Canggu. Alih fungsi lahan merupakan suatu tolok ukur untuk meningkatkan pendapatan ekonomi warga Desa canggu. Hal ini menyebabkan minat masyarakat menjadi meningkat untuk mengubah fungsi lahan mereka sebagai media penghubung perkembangan pariwisata tersebut. Faktor lain yang menyebabkan perubahan alih fungsi lahan di Desa Canggu adalah tingginya nilai permintaan dari wisatawan terhadap vasilitas yang disediakan. Kata kunci: Pariwisata dan alih fungsi lahan
\end{abstract}

\begin{abstract}
Canggu is a village located in North Kuta district, Badung Regency as the Central Badung Development Area which has a policy of maintaining Central Badung as an agricultural area in the broad sense and conversion of rice fields. The research question of this research is about research on land conversion. The selection of the Canggu village as a research location is because the Canggu village is in the middle of the Badung area as an agricultural, natural and cultural area such as the spirit of tourism in the Canggu village, the Canggu village works with the construction of recreational facilities. The type of data in this study is the source of qualitative and quantitative data from primary and secondary data. Research data were collected through interviews and library research. The determination of the informants of this study begins with determining the first informant and key informant. The data analysis technique of this research is descriptive qualitative analysis. According to the results of research in the village of Canggu obtained the
\end{abstract}


following results the development of tourism has an impact on increasing agricultural land conversion, land use changes also have an impact on sociocultural change. The research location is determined based on the development of tourism on land use change, the results of this study the development of tourism on land use change has an impact on the welfare of the people of Canggu Village. The land that has been converted has been built by hotels, homestays, villas, restaurants, laundry and others that support the interests of tourists, for a trip to Canggu Village. Transfer of land functions is a benchmark to increase the economic income of residents of Canggu Village. This causes the interest of the community to increase to change the function of their land as a media liaison with the development of tourism. Another factor causing changes in land use change in Canggu Village is the high value of requests from tourists for the facilities provided.

Keywords: Tourism and land use change

\section{PENDAhuluan}

Pemerintah Indonesia khususnya pemerintah daerah provinsi Bali sangat menggantungkan pendapatan atau devisa dari sektor Pariwisata. Hal ini karena sektor pariwisata merupakan sebuah industri yang perkembangannya sangat pesat dari tahun ke tahun dan investasi di sektor ini relatif menguntungkan karena bergantung pada citra dari daerah wisata yang bersangkutan, baik berkaitan dengan keindahan alamnya maupun karakter dan kebudayaan lokal dari daerah wisata yang bersangkutan. Di Indonesia sektor pariwisata dikembangkan sebagai sektor yang menjanjikan untuk mendatangkan pendapatan besar bagi negara terlebih di daerah-daerah yang memiliki sumber daya alam maupun sumber daya budaya yang melimpah. Berbagai potensi digali untuk menarik minat para wisatawan untuk datang berkunjung sehingga diharapkan mampu meningkatkan kesejahteraan masyarakat. Pulau Bali sebagai salah satu destinasi pariwisata di Indonesia memiliki keunikan yang khas bila dibandingkan dengan destinasi pariwisata lainnya. Keunikan dan potensi pariwisata Bali yang dikembangkan sebagai sebuah destinasi pariwisata berbasiskan pada budaya serta ditunjang oleh keindahan alam yang sangat menarik.

(Moga, 2010:16). Mengatakan bahwa penataan, pengelolaan dan pengembangan potensi pariwisata umumnya terdapat pada sumber daya alam (natural resources) yang bervariasi serta sumber daya budaya (cultural resources) yang beraneka ragam baik bentuk maupun karakter dari daya tarik itu sendiri. Pengembangan pariwisata Bali bertumpu pada tiga unsur. Ketiga unsur tersebut adalah masyarakat, alam, dan budaya.

Ketiga unsur tersebut berkolaborasi menjadi satu membentuk sebuah daerah tujuan wisata paling diminati yang kemudian harus dijaga demi keberlangsungan pariwisata Bali untuk kedepannya. Kabupaten Badung merupakan kabupaten yang memiliki beberapa daya tarik wisata unggulan. Kuta merupakan daerah tujuan wisata yang paling diminati oleh wisatawan baik domestik maupun mancanegara. Kegiatan wisata yang ada di Kuta umumnya berpusat di pantai Kuta. Munculnya pantai Kuta sebagai tempat yang paling diminati berdampak kepada kepariwisataan di daerah Kuta. Banyak perubahan terjadi akibat dari perkembangan pariwisata, namun yang paling menarik perhatian adalah tingginya tingkat 
pembangunan usaha akomodasi pariwisata dengan jumlah lahan yang sangat terbatas. Keterbatasan tersebut kemudian tidak serta merta menghentikan pembangunan bahkan mengakibatkan semakin tingginya tingkat alih fungsi lahan yang mengancam eksistensi ruang terbuka hijau yang juga berimbas ke daerah lain seperti di Desa Canggu, Kecamatan Kuta Utara. Alih fungsi lahan akibat pariwisata terlebihlebih alih fungsi lahan dari pertanian menjadi usaha akomodasi pariwisata merupakan masalah yang harus mendapatkan perhatian.

Jika berbicara tentang pariwisata di Kabupaten Badung dan Desa Canggu khususnya, kita harus menyadari bahwa alam dan budaya merupakan roh dari pariwisata. Jika hal ini dibiarkan bukan tidak mungkin pariwisata yang awalnya diharapkan mampu untuk meningkatkan kesejahteraan masyarakat justru mengancam kesejahteraan masyarakat itu sendiri. Sehingga dengan fenomena seperti ini, sangat menarik untuk menggali lebih jauh dampak yang ditimbulkan oleh pariwisata terhadap alih fungsi lahan dan sosial-budaya masyarakat lokal seperti yang terjadi di Desa Canggu, Kecamatan Kuta Utara, Kabupaten Badung.

Lahan merupakan sumber daya alam utama dalam menompang setiap aktivitas kehidupan manusia baik sebagai sumber daya yang dapat diolah maupun sebagai tempat tinggal terutama karena sifatnya yang permanen, tidak dapat dipindahkan serta unik. Karena itulah maka tidak mengherankan jika kemudian lahan menjadi tumpuan harapan dari berbagai kepentingan. Namun ketika sebidang lahan dapat digunakan untuk bermacam-macam keperluan, dan ketersediaannya yang terbatas, seringkali terjadi konflik diantara berbagai alternative penggunaan maupun peruntukan dalam pemanfaatannya.

Perkembangan pariwisata Desa Canggu Kecamatan Kuta Utara ini sangat dipengaruhioleh karakteristik fisik dan karakteristik sosial dan budaya daerah setempat. Karakteristik fisik berupa topografi yang bergelombang menyebabkan meratanya perkembangan yang terjadi. Pemusatan aktivitas penduduk lebih cepat terjadi dilokasi yang mempunyai topografi yang relatif datar. Sedangkan perkembangan yang disebabkan oleh karakteristik sosial dan budaya berkaitan dengan pertumbuhan penduduk Pertumbuhan penduduk di Kawasan Desa Canggu berpola linier dan pertumbuhannya tidak ada lonjakan yang berarti.dengan ciri tersebut yang ditandai dengan semakin berkembangnya kegiatan perkembangan pariwisata, sehingga alih fungsi lahan di Desa canggu menjadi melonjak. Aktivitas penduduk di kawasan tersebut saat ini berkembang dengan pesat. Oleh karena itu Kawasan Desa canggu terus mengalami pembangunan, maka terjadi perubahan penggunaan tata guna lahan yang cukup pesat, ini ditandai dengan banyaknya lahan pertanian menjadi lahan non pertanian. Daerah-daerah yang dulunya merupakan areal persawahan telah berubah menjadi areal permukiman, seperti antara lain Transformasi tata guna lahan persawahan ke tata guna lahan pemukiman yaitu villa, Hotel, Bar, Restoran, dan Homestay, yang terjadi di Desa Canggu, akan mempengaruhi struktur ruang Kawasan Desa Canggu. Akibat dari pemusatan lahan permukiman ini 
menyebabkan peningkatan harga lahan. Lahan semakin tinggi harga lahannya oleh karena banyak wisatawan asing yang membeli tanah di desa Canggu tersebut. Konversi lahan atau alih fungsi lahan pertanian menjadi lahan non pertanian sebenarnya bukan masalah baru. Pertumbuhan penduduk dan pertumbuhan perekonomian menuntut pembangunan infrastruktur baik berupa jalan, bangunan industri dan pemukiman, hal ini tentu saja harus didukung dengan ketersediaan lahan. Konversi lahan pertanian dilakukan secara langsung oleh petani pemilik lahan ataupun tidak langsung oleh pihak lain yang sebelumnya diawali dengan transaksi jual beli lahan pertanian. Faktor-faktor yang mempengaruhi pemilik lahan mengkonversi lahan atau menjual lahan pertaniannya adalah harga lahan, proporsi pendapatan, luas lahan, produktivitas lahan, status lahan dan kebijakan-kebijakan oleh pemerintah.

Kawasan desa Canggu termasuk dalam kawasan perkotaan sehingga mempunyai kegiatan utama bukan pertanian dengan susunan fungsi kawasan sebagai tempat permukiman perkotaan, pemusatan dan distribusi pelayanan jasa pemerintahan, pelayanan sosial. Menurut Undang-Undang Republik Indonesia Nomor 10 Tahun 2009 tentang kepariwisataan disebutkan bahwa pariwisata adalah berbagai macam kegiatan wisata dan didukung berbagai fasilitas serta layanan yang disediakan oleh masyarakat, pengusaha, pemerintah, dan pemerintah daerah. Pariwisata adalah keseluruhan kegiatan pemerintah, dunia usaha dan masyarakat untuk mengatur, mengurus dan melayani kebutuhan wisatawan.
(Karyono, 1997:15). Pariwisata merupakan rangkaian kegiatan yang dilakukan oleh manusia baik secara perorangan maupun kelompok di dalam wilayah negara lain. Kegiatan tersebut menggunakan kemudahan, jasa dan faktor penunjang lainnya yang diadakan oleh pemerintah dan atau masyarakat, agar dapat mewujudkan keinginan wisatawan.

Dari pengertian di atas menyimpulkan bahwa perkembangan pariwisata sangat memberi pengaruh terhadap alih fungsi lahan di Desa canggu Kecamatan Kuta Utara Kabupaten Badung.

\section{METODE}

Lokasi yang akan dijadikan tempat penelitian adalah di desa Canggu Kecamatan Kuta Utara, Kabupaten Badung. Dalam penelitian ini pendekatan yang di gunakan adalah pendekatan empiris. Jenis penelitian ini adalah data kualitatif, yaitu data yang digambarkan dengan kata-kata atau kalimat meliputi data mengenai gambaran umum desa dan data mengenai alih fungsi lahan Desa.

Teknik pengumpulan data dalam penelitian ini menggunakan Observasi, Wawancara dan Dokumentasi. Proses mencari dan menyusun data yang diperoleh dari hasil observasi, wawancara, studi pustaka, dan dokumentasi dijabarkan secara sistematis sehingga mudah dipahami dan temuannya dapat diinformasikan kepada orang lain yang disusun secara deskriptif kualitatif. 


\section{HASIL DAN PEMBAHASAN}

\section{Dampak Pariwisata Terhadap Alih}

\section{FUNGSI LAHAN}

Definisi mengenai konsep konversi lahan, yang dapat didefinisikan sebagai alih fungsi lahan dari fungsi semula dan dapat berdampak pada potensi lahan tersebut. Misal alih fungsi lahan pertanian dijadikan lahan industri atau lahan pemukiman. Fungsi awal lahan pertanian adalah untuk menghasilkan produksi pertanian pangan akan tetapi beralih fungsi menjadi lahan industri atau lahan pemukiman. Maka dari itu akan berdampak dengan hasil pertanian pangan yang merupakan potensi sebuah lahan pertanian. Masalah alih fungsi lahan telah dijelaskan diatas adalah berkaitan dengan kebijakan publik. Maka dari itu penyebab dari sebuah alih fungsi lahan kemungkinan bisa karena kebijakan publik sendiri. Berbagai masalah yang muncul dengan alih fungsi lahan juga bisa jadi terkait dengan kinerja implementasai kebijakan publik yang bermasalah pula.

Pada gambar dibawah ini merupakan alih fungsi lahan sawah di desa Canggu yang akan mendirikan Villa.

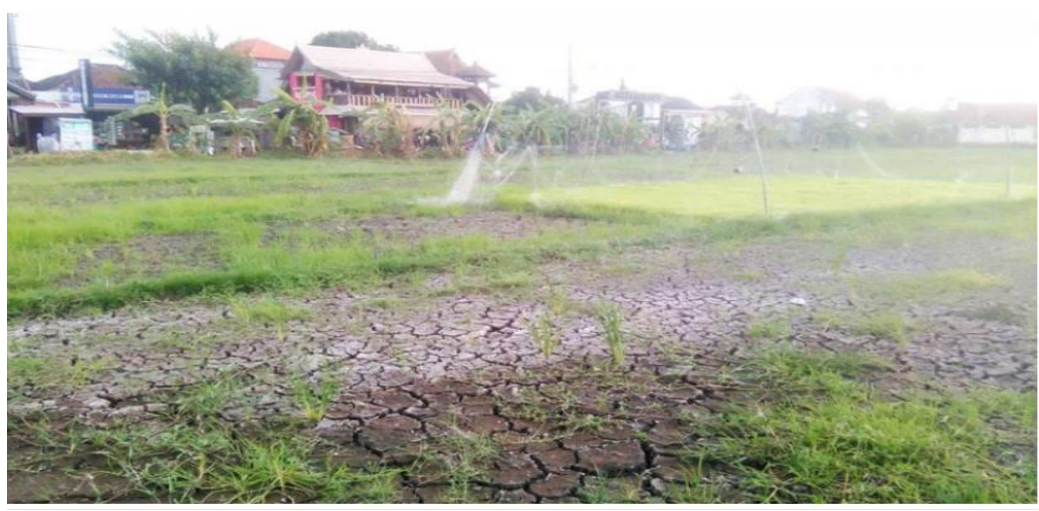

Gambar 1. lahan persawahan yang kering

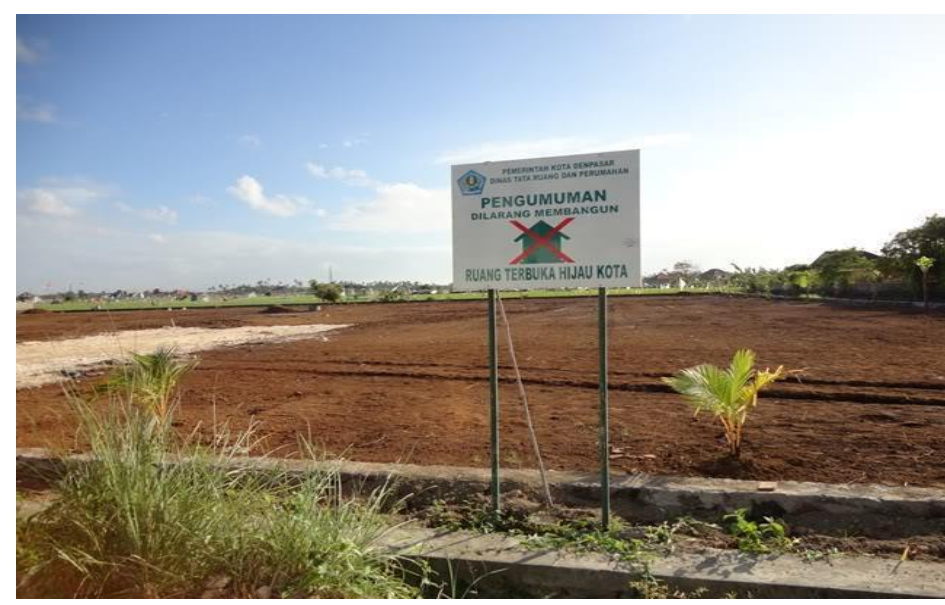

Gambar 2. lahan persawahan yang dipakai untuk membangun lapangan 
lagi. Gencarnya perkembangan pariwisata membawa pengaruh dan efek negatif terutama bagi alam dan sosial-budaya masyarakat. Kegiatan pariwisata yang erat kaitanya dengan proses sosial secara perlahan mulai mempengaruhi semua elemen didalam pariwisata termasuk masyarakat.

Soerjono Soekanto (2005) mengenai analisisnya yang sering kita ketahui adalah manifestasi dan latency. Suatu proses sosial mempuyai sebuah kecenderungan harapan yang diinginkan dari suatu proses sosial yang terjadi yang disebut manifestasi namun ada bentukbentuk yang tidak diharapkan dalam proses sosial tersebut, tapi secara alamiah selalu menyertai atau muncul yang disebut sedangkan latency. Proses kegiatan pariwisata yang ada di Desa Canggu serupa dengan apa yang disebut sebagai manifestasi dan latency oleh Suejono. Kegiatan pariwisata yang berlangsung di Desa Canggu memunculkan harapan bagi masyarakat untuk mendapatkan keuntungan yang sebesarbesarnya dari kegiatan tersebut. Harapan untuk mendapatkan keuntungan dari kegiatan pariwisata kemudian diwujudkan oleh masyarakat melalui penyediaan layananlayanan pariwisata untuk melengkapi kebutuh wisatwan yang berkunjung seperti pembangunan sarana akomodasi pariwisata seperti hotel, villa, dan guest house. Dari sini kemudian masyarakat Desa Canggu memperoleh keuntungan terutama finansial yang sangat besar. Secara tangible pertumbuhan jasa penginapan untuk wisatwan di Desa Canggu seperti villa dan guest house ternyata banyak berdampak negatif. Dan jika dikaitkan dengan pendekatan manifestasi dan latency, fenomena ini adalah latency atau sebuah bentuk yang tidak diharapkan dari proses perkembangan pariwisata yang secara alamiah selalu menyertai atau muncul. Adapun dampak negatif tersebut adalah dampak terhadap tata-guna lahan pertanian yang terancam eksistensinya karena pembangunan villa dan guest house yang dikelola masyarakat sebelumnya, dibangun diatas lahan persawahan.

\section{Kehidupan Sosial Masyarakat}

Dampak pariwisata terhadap tata-guna lahan seperti berahihnya fungsi lahan pertanian menjadi sarana akomodasi pariwisata memberikan dampak sosial bagi masyarakat Desa Canggu yang dapat dilihat dari mobilitas penduduk dan terhadap mata pencaharian (perubahan pekerjaan). Perkembangan pariwisata mulai bergeliat sejak tahun 1980-an yang ditandai dengan berdirinya hotel pertama Dewata Beach Hotel secara perlahan menunjukan dampaknya terhadap jumlah penduduk. Contoh kasus yang terjadi di Desa Canggu.

Menurut I Nengah Diraga Yusa selaku Kelian Dinas Desa Canggu sebelum pariwisata masuk ke Desa Canggu, populasi penduduk di Desa Canggu sangat kecil yaitu hanya 13 kepala keluarga. Kepala Keluarga tersebut memiliki ikatan yang sangat dekat dalam hal berhubungan sosial. Antar kepala keluarga di Desa Canggu merupakan "tugelan" atau dalam bahasaIndones berarti saudara.

Dalam hal keseharian ada aspek-aspek yang tidak dapat dipisahkan yang tidak dimiliki di daerah lain seperti kedekatan dalam komunikasi dan silaturahmi yang menjadi ciri khas masyarakat Bali pada umumnya. Hingga saat ini dari 13 Kepala Keluarga tersebut telah 
berkembang menjadi 31 Kepala Keluarga. Semakin banyaknya jumlah penduduk memberikan dampak terhadap kehidupan sosial warga masyarakat.

Banyaknya jumlah penduduk yang tinggal di Desa Canggu berdampak terhadap tingkat kriminalitas yang terjadi belakangan ini. I Nengah Diraga Yusa, menyampaikan ada beberapa kasus pernah terjadi di Desa Canggu seperti pencurian di tempat penginapan wisatwan. Bahkan tingkat kriminalitas berupa pencurian semakin marak terjadi. Hal ini dipandang sebagai hal yang sangat mengkawatirkan karena semakin pesatnya perkembangan pariwisata dan jumlah penduduk tidak diimbangi dengan tingkat kemanan yang ada di desa. Tidak saja masalah keamanan yang menjadi masalah di Desa Canggu. Masalah kebersihan juga sedang dihadapi oleh warga desa. Semakin banyaknya jumlah penduduk mengakibatkat jumlah sampah yang diproduksi semakin banyak. Sampah yang muncul ini ternyata tidak diimbangi oleh tempat pembuangan akhir (TPA) yang memadai.

Di Desa Canggu sendiri tidak ada tempat pembuangan akhir untuk sampah-sampah yang diproduksi. Sampah yang dihasilkan biasanya dibuang di tempat pembuangan sementara yang ada di Banjar Tandeg untuk kemudian menungu petugas sampah untuk mengangkut dan di buang di TPA yang terdapat di Denpasar. Dari sisi mata pencaharian, kegiatan pariwisata memberikan peluang yang besar bagi masyarakatnya untuk bekerja dan senantiasa terbuka baik yang bersifat formal maupun informal. Dari sisi informal masyarakat diberikan keuntungan dari kegiatan pariwisat yang cukup besar.

\section{Alih Fungsi Lahan di Desa Canggu}

Alih fungsi (konversi) lahan merupakan proses perubahan penggunaan fungsi sebagian atau seluruh kawasan lahan dari fungsi semula menjadi fungsi yang lainnya. Alih fungsi lahan ini terjadi secara dinamis dan perubahannya cenderung mengarah pada semakin meningkatnya jumlah populasi penduduk. Manusia menggunakan dan memanfaatkan sumber daya lahan untuk mencukupi berbagai kebutuhannya seperti: tempat tinggal (pemukiman), industri, pertokoan, perkantoran, dan infrastrukur lainnya. Hal inilah yang menjadikan ketersediaan sumber daya lahan menjadi sebuah tuntutan kebutuhan yang harus terpenuhi untuk menunjang kegiatan ekonomi masyarakat. Untuk mencukupi kebutuhan lahan tersebut maka acapkali terjadi persaingan penggunaan lahan yang pada akhirnya akan menggeser ketersediaan lahan pertanian menjadi lahan non pertanian.

Secara tangible dampak dari kegiatan pariwisata yang terjadi di Desa Canggu memberikan bukti bahwa kegiatan pariwisata saat ini hanya berorientasi kepada kuantitas dan pembangunan setinggi-tingginya. Tercermin dari apa yang terjadi saat ini, kegiatan pariwisata mulai meberikan dampak terhadap konvensi lahan pertanian menjadi sarana akomodasi yang semakin pesat setiap tahunnya. Desa Tibubeneng secara administratif masuk ke dalam wilayah Badung Tengah yang memiliki kebijakan mempertahankan lahan pertanian, secara perlahan menunjukan peningkatan alih 
fungsi lahan di bidang pertanian ke nonpertanian.

Dari data yang diperoleh dari Profil Perkembangan Desa Canggu (2011) luas lahan pertanian dan lahan kering/tegalan tahun 2011 seluas 302,30 hektar (Ha). Kini lahan tersebut semakin menyempit dengan sisa luas 260 hektar (Ha) atau $40 \%$ dari total luas lahan di Desa Canggu. Artinya dari tahun 2011 sampai pertengahan tahun 2013 Desa Canggu telah mengalami konvensi lahan seluas 42,30 Ha.

Jika dilihat dari pernyataan tersebut, tersirat bahwa pertumbuhan villa dan guest house tersebut semakin mengancam keberadaan sawah yang ada di Desa Canggu. Dengan demikian, Desa Canggu yang masuk ke dalam Kawasan Kuta Utara sebagai Wilayah
Pengembangan Badung Tengah yang dikategorikan sebagai kawasan agraris merujuk RT/RW Kabupaten Badung 2010-2030 bisa dipertanyakan. Masih pantaskah kawasan Kuta Utara khususnya Desa Canggu ini ditetapkan sebagai kawasan pertanian ditengah pelanggaran kebijakan mempertahankan wilayah Badung Tengah sebagai kawasan pertanian dalam arti luas dan mencegah alih fungsi lahan sawah dengan meningkatkan produktivitas dan pendapatan petani mengalami bayak pelangaran di berbagai sisi.

Pada gambar dibawah akan dijelaskan bagaimana pengalihan fungsi lahan di desa Canggu yaitu dari lahan persawahan, dialihkan ke pembangunan Vila, Home stay, Café dan lain sebagainya.

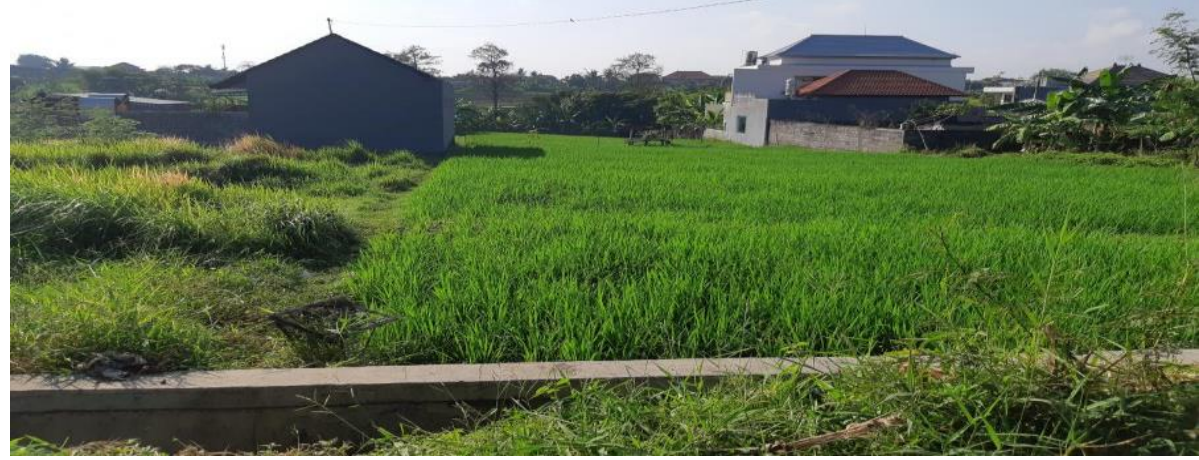

Gambar 3. lahan sawah dialihkan ke pembangunan villa dan home stay

\section{Kebudayaan Masyarakat}

Seperti umumnya desa-desa yang ada di Bali, Desa Canggu merupakan desa yang memiliki kebudayaan yang hampir sama dengan daerah lainya. Kegiatan ritual keagamaan, pertunjukan, kelompok atau seka yang dimiliki hampir tidak ada perbedaan dengan daerah lain. Kelompok dan perkumpulan atau seka yang ada telah terbentuk sejak dahulu dan merupakan warisan leluhur. Kelompok dan sekaa ini masih tetap bertahan bersama organisasi sosial desa seperti subak. Namun secara tangible mengalami perubahan dimana perubahan tersebut erat kaitanya dengan perkembangan pariwisata yang saat ini berlangsung.

Berkurangnya seka subak berdampak kepada hilangnya budaya mengaturkan ritual persembahan berupa banten ke sawah oleh 
beberapa orang yang biasanya dilakukan setiap enam bulan sekali. Ritual ini merupakan simbolik rasa sukur terhadap penguasa padi yaitu Dewi Istri dan penunggu sawah yaitu Betari Sri karena telah diberikan kelancaran dalam mengelola sawah. Kini kebudayaan tersebut telah hilang di sebagian besar individu digantikan oleh kegiatan lain yang jauh dari kebudayaan tradisional masyarakat. Artinya secara eksplisit individu yang telah menjual atau mengalihfungsikan lahannya menjadi lahan non-pertanian telah keluar dari keikut sertaanya di dalam organisasi subak, budaya-budaya yang ada di dalam organisasi subakpun tidak dapat lagi dilakukan dan mengancam dari kelestarian budaya yang telah ada ratusan tahun yang lalu ini.

Bagi generasi penerus hal ini sangatlah memperihatinkan, budaya pernah menjadi bagian di dalam kehidupan masyarakat ini tidak bisa diwariskan kepada anak cucu mereka.

\section{Pergeseran Nilai dan Solidaritas Masyarakat}

Pengaruh yang dibawa oleh pariwisata secara perlahan mulai masuk kedalam kehidupan masyarakat. Secara intangible perkembangan pariwisata mulai berdampak terhadap kehidupan masyarakat dengan mulai bersikap terbukanya masyarakat terhadap wisatwan. Dengan sikap yang terbuka itu kemudian wisatawan sedikit demi sedikit mulai berpartisipasi secara langsung dengan ikut serta didalam kegiatan ritual masyarakat. Partisipasi wisatawan di setiap kegiatan ritual di desa memunculkan sebuah perubahan terhadap nilainilai kesakralan upacra agama. Ritual yang dahulu dianggap sangat sakral seperti upacara adat masyarakat yang seyogyanya dilakukan hanya oleh orang-orang yang memiliki hubungan khusus yang kuat dengan upacara tersebut semisal hanya bagi orang-orang memiliki hubungan darah atau dalam bahasa Bali disebut "tunggalan", kini sudah mulai mengarah ke arah yang lebih terbuka, tidak saja keluarga dekat saja yang bisa melakukannya namun juga bisa di lakukan oleh wisatwan asing yang tinggal di desa.

Disisi lain, Pitana dan Gayarti (2005:94). mengatakan kegiaan pariwsata disuatu daerah dikatakan telah mengahncurkan sifat-sifat kebersamaan didalam masyarakat dan kemudian digantikan oleh sifat individualisme pragmatis. Sebelum masuknya pariwisata mayarakat yang sebagaian besar belum bergelut dalam bisnis pariwisata memiliki tingkat partisipasi yang tinggi didalam berorganisasi dan memiliki waktu luang yang cukup untuk berorganisasi. Seiring pertumbuhan pariwisata, kesibukan semakin bertambah, dan sering mengorbankan kegiatan didalam masyarakat. Masyarakat yang lahanya kini diperuntukan untuk penyewaan penginapan untuk wistawan memiliki tingkat kesibukan yang sangat tinggi. Secara intangible terlihat ada sebuah pergerakan dari masyarakat yang kini cenderung berorientasi kearah keuntungan secara finansial atau profit oriented.

Pariwisata dipandang sebgai kegiatan yang menguntungkan dan mampu mendatangkan pendapatan yang besar. Sehingga banyak dari mereka yang memutuskan untuk mengeluti dunia pariwisata meski ada banyak hal yang harus dikorbankan termasuk waktu luang. Terbatasnya waktu luang akhirnya 
membuat seseorang harus memilih. Disinilah sifat individualisme mulai muncul di dalam diri masyarakat. Dampaknya, seseorang lebih memilih sesuatu yang dirasa lebih menguntukan untuk dirinya dan mengabaikan kepentingan di masyarakat seperti partisipasinya didalam berorganisasi. Pandangan-pandangan seperti ini mulai muncul ketika pariwisata mulai berkembang. Perkembangan pariwisata banyak memberikan pilihan-pilihan yang memaksa beberapa pihak untuk bertindak di luar jalur yang semestinya mereka lakukan. Budaya hidup yang menempatkan kepentingan pribadi di bawah kepentingan secara perlahan telah berubah digantian pandangan baru yang tentunya jika dikaitakn dengan budaya orang Bali akan bertolak belakang. Secara kasat mata pariwisata mempengaruhi sifat-sifat individu dalam mengambil kepeutusan. Terabaikannya anggapan bahwa kita harus mementingkan kepentingan umum sebelum kepentingan pribadi memunculkan sifat-sifat individualisme didalam pengambilan keputusan tersebut. Sifat "menyama braya" atau bermasyarakat, secara intangible mulai sedikit berubah mengarah kesifat individualis yang dalam kehidupan bermasyarakat bisa berdampak negatif seperti mulai munculnya stigma negatif yang bisa memunculkan konflik.

\section{Hasil Penelitian}

Berdasarkan hasil wawancara dengan Kepala Desa Canggu, Kelian Dinas Desa Canggu dan dua orang warga desa meliputi : (1) Perkembangan pariwisata menjadi optimal karena banyaknya fasilitas-fasilitas yang disediakan warga desa Canggu seperti Villa, Home Stay, Hotel, Barr, Club, Restaurant, cafe dan fasilitas lainnya. (2) Sebelum adanya pengalihan fungsi lahan di desa Canggu, warga desa tidak memiliki asupan pendapatan yang baik untuk peningkatan ekonomi karena di dasarkan oleh pekerjaan sebagai nelayan, penjaga toko, bercocok tanam dan lain sebagainya. (3) Fungsi pengalihan alih fungsi lahan di desa Canggu bukan semata-mata untuk kepentingan warga setempat. pengalihan fungsi lahan ini sebagai dasar atau fondasi kenyamanan warga desa Canggu dalam rangka peningkatan ekonomi, (4) Warga desa Canggu memiliki motivasi untuk pengembagan pariwisata dengan melakukan alih fungsi lahan sebagai fondasi utama untuk melengkapi proses pengembangan pariwisata desa Canggu.

Berdasarkan uraian diatas bahwa pengaruh perkembangan pariwisata terhadap alih fungsi lahan cukup memiliki manfaat terhadap pengembangan pariwisata berkelanjutan kedepannya, dan dari tujuan peneliti hasil penulisan ini dapat memberikan acuan atau pedoman bagi masyarakat setempat untuk lebih menganalisis bagaimana pengaruh perkembangan pariwisata seterusnya. Alih fungsi lahan memiliki peran positif dalam perkembangan pariwisata di desa Tibubenng, selain mempengaruhi ekonomi masyarakat, alih fungsi lahan ini juga mempengaruhi Gaya hidup warga desa Canggu.

Dampak Pariwisata terhadap alih fungsi lahan di desa Canggu, Kecamatan Kuta Utara kabupaten Badung meliputi dampak tangible dan dampak intangible. Secara Tangible dampak pariwisata terhadap alih fungsi lahan mengakibatkan semakin banyaknya pembangunan sarana akomodasi yang semakin 
mengancam kelestarian lahan persawahan. Pembangunan sarana akomodasi kemudian juga berdampak terhadap jumlah penduduk yang memicu masalah-masalah social seperti meningkatnya kriminaltas seperti pencurian dan masalah produksi sampah yang tidak diimbangi oleh tempat pembuangan akhir (TPA) yang memadai. Perkembangan sarana akomodasi juga berdampak terhadap perubahan pekerjaan dari yang mulai mengarah kepekerjaan dibidang pariwisata. Disisi kebudayaan dampak pariwisata secara tangible juga mengakibatkan hilangnya budaya mengaturkan persembahan berupa banten yang biasanya dilakukan setiap enam bulan sekali sebagi symbol rasa syukur terhadap penguasa padi yaitu dewi istri dan penungggu sawah yaitu Betari Sri. Secara intangible dampak pariwisata terhadap alih fungsi lahan mengakibatkan menghilangkan nilai kesakralan ritual keagamaan desa adat dan tumbuhnya sifat individualis yang berpandangan profit oriental.

\section{PENUTUP}

Alih fungsi (konversi) lahan merupakan proses perubahan penggunaan fungsi sebagian atau seluruh kawasan lahan dari fungsi semula menjadi fungsi yang lainnya. Alih fungsi lahan ini terjadi secara dinamis dan perubahannya cenderung mengarah pada semakin meningkatnya jumlah populasi penduduk. Manusia menggunakan dan memanfaatkan sumber daya lahan untuk mencukupi berbagai kebutuhannya seperti: tempat tinggal (pemukiman), industri, pertokoan, perkantoran, dan infrastrukur lainnya. Hal inilah yang menjadikan ketersediaan sumber daya lahan menjadi sebuah tuntutan kebutuhan yang harus terpenuhi untuk menunjang kegiatan ekonomi masyarakat. Untuk mencukupi kebutuhan lahan tersebut maka acapkali terjadi persaingan penggunaan lahan yang pada akhirnya menggeser ketersediaan lahan pertanian menjadi lahan non pertanian. Pengembangan pariwisata yang maju dapat menghasilkan berbagai efek yang menguntungkan pendapatan daerah dan masyarakat setempat. Pengembangan pariwisata yang baik dapat menciptakan berbagai efek yang salah satunya adalah kemajuan pariwisata di desa Canggu.

\section{DAFTAR PUSTAKA}

Faizun, Moh. 2009. Dampak Perkembangan Kawasan Wisata Pantai Kartini yarakat Setempat di Kabupaten Jepara. Tesis Program Pascasarjana Universitas Diponegoro Semarang.

I Gusti Bagus, dan Ni Made Eka M. 2012. Metodologi Penelitian Pariwisata Dan Perhotelan. Yogyakarta: CV Andi Offet

Inskeep, Edward. 1991. Tourism Planning: An Integrated and Sustainable Development Approach. New York: Van Nostrand Reinhold.

Ibrahim. 1993. Dampak Pengenmbangan Pariwisata Terhadap Kehidupan Social. Jawa Tengah: Departemen Pendidikan Dan Kebudayaan

J.R. Brent Ritchie and Charles R. Goeldner (Ed.) 1987. Travel, Tourism and Hospitality Research. New York. John Wiley and Sons Inc.

Koentjaraningrat. 1977. Metode-Metode Penelitian Masyarakat. Jakarta: Pt. Gramedia.

Kartika, I Made \& Mahendra, Putu Ronny Angga. Tri Hita Karana Sebagai Landasan Mewujudkan Kepemimpinan Pancasila. Universitas Dwijendra 
Denpasar : Prosiding Seminar Nasional Inovasi dalam Penelitian Sains, Teknologi dan Humaniora - InoBali 2019 hal $222-228$

Karyono, A. Hari. 1997. Kepariwisataan. Jakarta: Gramedia Widiasarana Indonesia.

Lewis, JHon. 1998. Tourism and Development In Third Word Countries. Clays Ltd. England.

Lean W. And B. Goodall. 1996. Aspect of Land Economics. Bath: Putmann Press.

Mahendra, Putu Ronny Angga. Menjawab Tantangan Baru Pendidikan Kewarganegaraan pada Level Publik. IHDN Denpasar : Jurnal Pendidikan Dasar Adi Widya Vol. 4 No. 1 April 2019 hal 1-7.

Mahendra, Putu Ronny Angga. Sistem Pembagian Tanah Ulayat pada Masyarakat Manggarai Suku Langkat Kelurahan Carep Kecamatan Langke Tembong Kabupaten Manggarai (Tinjauan Nilai-Nilai Pancasila). Jurnal Pendidikan Kewarganegaraan Undiksha Vol.8 No.1 Tahun 2020 hal 106 - 112.

Oka Yoeti. 2007. Perencanaan Dan Pengembangan Pariwisata. Jakarta: Pt. Pradnya Paramita

Oka Yoeti. 2008. Ekonomi Pariwisata: Introduksi, Informasi, Dan Aplikasi. Jakarta: Kompas 